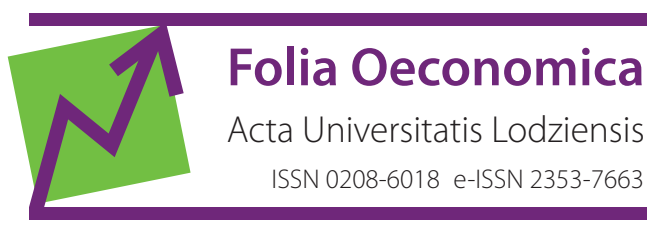

www.czasopisma.uni.lodz.pl/foe/

5(331) 2017

DOI: http://dx.doi.org/10.18778/0208-6018.331.05

\author{
Anna Majdzińska \\ Uniwersytet Łódzki, Wydział Ekonomiczno-Socjologiczny, Zakład Demografii i Gerontologii \\ Społecznej, a_majdzinska@uni.lodz.pl
}

\title{
Zróżnicowanie terytorialne starzenia się ludności Polski
}

\begin{abstract}
Streszczenie: W opracowaniu przedstawiona została analiza zmian w strukturze wieku ludności Polski, obserwowana od początku okresu transformacji ustrojowej i spodziewana w perspektywie następnych lat. Analiza ta została pogłębiona badaniem przestrzennego zróżnicowania zaawansowania starości demograficznej (ocenionej za pomocą kilku mierników) oraz dynamiki procesu starzenia się w Polsce w latach 2002, 2014 i 2020, przeprowadzonym na poziomie województw, powiatów i gmin. Źródło danych wykorzystanych w badaniu stanowiły informacje dotyczące struktury wieku ludności w Polsce i w mniejszych jednostkach terytorialnych, opublikowane przez Główny Urząd Statystyczny.
\end{abstract}

Słowa kluczowe: demograficzne starzenie się ludności, miary starości, Polska, województwa

JEL: J1

\section{Wprowadzenie}

Proces demograficznego starzenia się ludności definiowany jest jako sukcesywny wzrost liczby i udziału ludności starszej w populacji (Holzer, 2003: 139), przy czym jako próg starości obecnie przyjmowany jest wiek 65 lat. Należy podkreślić, że granica ta nie jest stała i z uwagi na postęp tego procesu ulegała stopniowemu podwyższeniu na przestrzeni minionych dekad. Problem demograficznego starzenia się populacji dotyczy krajów, które doświadczyły przejścia demograficznego w jego klasycznej postaci ${ }^{1}$ (Uhlenberg, 2005: 147). Obecnie głównymi czynnika-

${ }^{1}$ Przejście demograficzne to teoria opisująca przemiany społeczeństw w zakresie typu reprodukcji (od tradycyjnego, legitymującego się wysokimi stopami urodzeń i zgonów, do nowoczesnego, charakteryzującego się niskim poziomem rozrodczości i umieralności). Zarówno przed, jak i po zakończeniu przejścia demograficznego, przyrost naturalny jest niski - bliski zeru (Kirk, 1996: 361, Okólski, 1990: 18-19; Okólski, Fihel, 2012: 113). Z kolei przemiany w sferze reprodukcji ludności w krajach doświadczających schyłku przejścia w jego klasycznej postaci, związane ze zmia- 
mi determinującymi ten proces $\mathrm{w}$ krajach europejskich są: zmniejszający się poziom dzietności (niezapewniający zastępowalności generacji) ${ }^{2}$ i wydłużanie się przeciętnego dalszego trwania życia ludności. Istotne znaczenie w tym względzie odgrywają również migracje, które mogą hamować bądź przyspieszać jego postęp na danym obszarze ${ }^{3}$. Wzrastający odsetek subpopulacji osób starszych, przy zmniejszającym się udziale frakcji młodszych, generuje wiele następstw, w większości negatywnych (m.in. spadek wydolności systemów emerytalnych, zmniejszanie się potencjalnych zasobów pracy, wzrost kosztów opieki zdrowotnej i opieki społecznej nad seniorami $)^{4}$.

Istnieje wiele mierników oceny zaawansowania procesu starzenia się populacji. Najczęściej w tym celu wykorzystywany jest odsetek ludności w wieku 65 lat i więcej. Spośród pozostałych mierników częste zastosowanie znajdują także: mediana wieku ludności, indeks starości (obliczany jako iloraz liczby osób w wieku 65+ i liczby dzieci w wieku 0-14 lat), odsetek ludności sędziwej (tj. będącej w wieku 80+), indeks sędziwej starości (obliczany jako iloraz liczby osób w wieku 80+ do liczby seniorów w wieku 65+), a także współczynnik obciążenia demograficznego osobami starszymi (liczony jako iloraz liczby osób w wieku 65+ do liczby osób w wieku 15-64 lata) czy współczynnik potencjalnego wsparcia (będący odwrotnością współczynnika obciążenia) ${ }^{5}$.

Polska obecnie legitymuje się relatywnie niższym zaawansowaniem starości demograficznej niż kraje Europy Zachodniej i Południowej, jednakże w perspektywie kilku kolejnych lat należy spodziewać się akceleracji procesu starzenia się, głównie ze względu na przekraczanie progu starości przez liczne roczniki wyżu

ną wzorca matrymonialno-prokreacyjnego (przejawiające się m.in. spadkiem poziomu dzietności poniżej poziomu zapewniającego prostą zastępowalność generacji), objaśniane są na gruncie koncepcji drugiego przejścia demograficznego (zob. Kotowska, 1999: 13, 16-17; Lesthaeghe, 2010: 5; van de Kaa, 2002: 910).

${ }^{2}$ Spadku poziomu dzietności najwcześniej doświadczyły kraje Europy Północnej i Zachodniej (koniec XIX wieku), ale obecnie czynnik ten silnie oddziałuje na strukturę wieku populacji większości krajów europejskich. W Polsce od końca lat osiemdziesiątych XX wieku współczynnik dzietności nie gwarantuje prostej zastępowalności generacji. W 2014 roku miernik ten wyniósł 1,3 (w miastach i na wsi odpowiednio 1,2 i 1,4).

${ }^{3}$ Proces demograficznego starzenia się populacji rozpoczął się na początku XX wieku w rozwiniętych gospodarczo krajach Europy Zachodniej (Kurek, 1998: 262). W Polsce, podobnie jak w pozostałych krajach postsocjalistycznych, akceleracja procesu starzenia się miała swój początek w latach dziewięćdziesiątych XX wieku (Gavrilova, Gavrilov, 2009: 115116). Opis przyczyn procesu starzenia się oraz jego przebieg $\mathrm{w}$ aspekcie globalnym zostały przedstawione m.in. w opracowaniu D.T. Rowland (2009: 37-46).

${ }^{4}$ Więcej na temat konsekwencji demograficznego procesu starzenia się populacji zostało przedstawione m.in. w opracowaniach: GUS (2014c), A. Kalache i in. (2005), J. Kurkiewicz (2010), J. Kurkiewicz (2012), S.A. Nyce, S. Schieber (2011).

${ }^{5}$ Więcej na temat miar zaawansowania starości demograficznej można przeczytać m.in. w opracowaniach: A. Abramowska-Kmon (2011), M. Cieślak (2004), Z. Długosz (1998), J.T. Kowaleski, A. Majdzińska (2012), J. Kurkiewicz (2010; 2012). 
demograficznego z lat pięćdziesiątych XX wieku. Wewnątrz kraju widoczne jest terytorialne zróżnicowanie zaawansowania starości demograficznej - wyższe obserwowane jest w części centralnej i wschodniej oraz w dużych miastach. Dynamika starzenia się populacji również nie jest jednakowa - w niedalekim horyzoncie czasowym szybciej starzeć się będą obszary obecnie legitymujące się niższym zaawansowaniem tego procesu.

Celem opracowania jest analiza przestrzennego zróżnicowania starości demograficznej w Polsce oraz ocena dynamiki procesu starzenia się populacji. Na poziomie kraju badanie to zostało przeprowadzone w latach 1990-2014 oraz dla roku 2020, natomiast w przekroju terytorialnym (tj. na poziomie województw, powiatów i gmin) w latach 2002, 2014 i dla roku 2020. Źródłem danych wykorzystanych w dalszych analizach były informacje dotyczące struktury wieku ludności w Polsce i w jednostkach terytorialnych niższego szczebla agregacji danych, zamieszczane na stronie internetowej Głównego Urzędu Statystycznego ${ }^{6}$.

\section{Obraz struktury wieku populacji Polski w latach 1990-2014 oraz do 2020 roku}

Na przestrzeni minionych dwóch dekad struktura wieku populacji Polski uległa wyraźnemu przeobrażeniu, polegającemu głównie na zwiększeniu się frakcji osób starszych i zmniejszeniu się odsetka dzieci. W celu zobrazowania tych przemian poniżej przedstawione zostały udziały ludności w grupach wiekowych 0-14 lat, 15-64 lata i 65+ lat, a także wartości indeksu starości oraz mediana wieku ludności w latach 1990-2014 oraz w 2020 roku (ogółem i w przekroju miasto-wieś).

W Polsce w 2014 roku udział dzieci w wieku 0-14 lat wyniósł 15\% (w miastach $14 \%$, na wsi zaś $16,5 \%$ ) i był o 9,4 p.p. niższy względem roku 1990, kiedy to frakcja dzieci stanowiła blisko $1 / 4$ ogółu populacji (zob. rys. 1). Subpopulacja ta charakteryzuje się tendencją malejącą od połowy lat osiemdziesiątych XX wie$\mathrm{ku}$, ale według prognozy GUS w perspektywie kolejnych kilku lat jej odsetek w populacji utrzyma się na poziomie zbliżonym do obecnie obserwowanego - przykładowo w roku 2020 wyniesie on $14,8 \%$ (w miastach i na wsi odpowiednio $14 \%$ i $16,1 \%)$.

W 2014 roku udział ludności w wieku 15-64 lata wyniósł 69,8\% i osiągnął niemalże taką samą wartość w miastach i na wsi (zob. rys. 2). Na początku okresu transformacji ustrojowej odsetek ten był o 4,4 p.p. niższy niż obecnie (co wynikało z relatywnie wysokiej frakcji dzieci, obecnie zasilającej środkową grupę wieku), przy

${ }^{6}$ Dane dla roku 2020 zostały zaczerpnięte z prognozy ludności opracowanej przez GUS w 2014 roku, sporządzonej na bazie informacji pochodzących z Narodowego Spisu Powszechnego Ludności i Mieszkań, przeprowadzonego w 2011 roku. 
czym wyraźna była jego przewaga w miastach. W ciągu najbliższych kilku lat spodziewany jest spadek udziału omawianej subpopulacji - przykładowo w roku 2020 wyniesie on $66,3 \%$ (w miastach i na wsi odpowiednio $65,2 \%$ i $67,9 \%$ ).

Od początku okresu transformacji ustrojowej obserwowany jest sukcesywny wzrost udziału ludności w wieku 65+ (zob. rys. 3). W Polsce w 2014 roku odsetek tej subpopulacji wyniósł $15,3 \%$ (w miastach $16,3 \%$ i na wsi $13,6 \%$ ) i względem roku 1990 wzrósł o 5,1 p.p. Należy podkreślić, że od 10 lat miernik ten osiąga wartości wyższe w miastach (do 2005 roku wyższym udziałem osób starszych legitymowała się wieś). W perspektywie kilku kolejnych lat należy spodziewać się dalszego postępu procesu starzenia się populacji - w roku 2020 odsetek ludności w wieku $65+$ prawdopodobnie wyniesie $18,9 \%$ (w miastach i na wsi odpowiednio $20,8 \%$ i $16 \%)$.

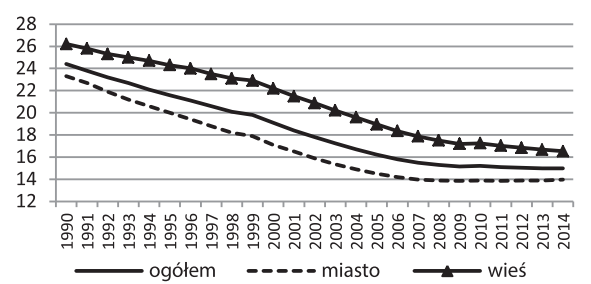

Rysunek 1. Udziały ludności w wieku 014 lat w Polsce w latach 1990-2014 (w \%)

Źródło: GUS; opracowanie własne

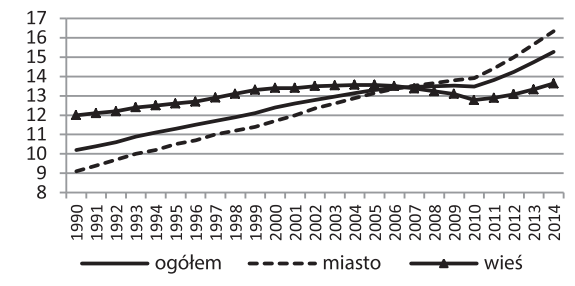

Rysunek 3. Udziały ludności w wieku 65+ w Polsce w latach 1990-2014 (w \%)

Źródło: GUS; opracowanie własne

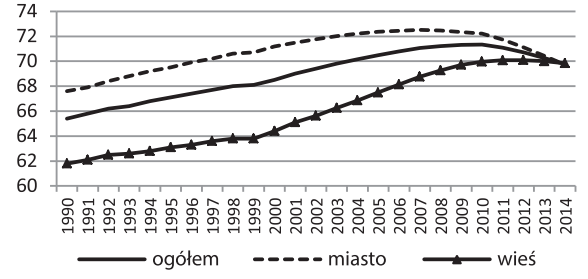

Rysunek 2. Udziały ludności w wieku 15-64 lata w Polsce w latach 1990-2014 (w \%)

Źródło: GUS; opracowanie własne

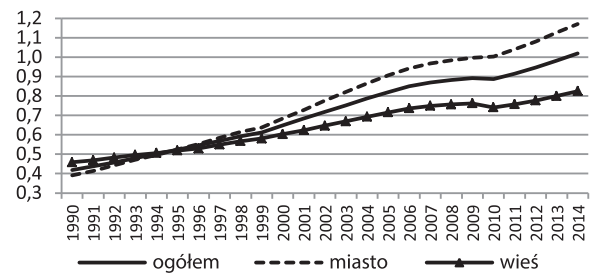

Rysunek 4. Wartości indeksu starości $\left(L_{65+} /\right.$ $\left.L_{0-14}\right)$ w Polsce w latach 1990-2014 Źródło: GUS; opracowanie własne

W związku ze zmianami w zakresie struktury wieku ludności zasadniczej zmianie uległy wartości indeksu starości, osiągające na początku okresu transformacji ustrojowej relatywnie niski poziom (zbliżony w miastach i na wsi), świadczący o znacznej liczebnej przewadze frakcji dzieci nad subpopulacją osób starszych (zob. rys. 4). W Polsce w 2014 roku starsza z tych subpopulacji po raz pierwszy była liczniejsza od młodszej i w rezultacie na 100 dzieci w wieku 0-14 lat przypadały 102 osoby starsze (w miastach i na wsi odpowiednio 117 i 83 osoby). W świe- 
tle prognoz GUS rosnąca tendencja wartości indeksu starości utrzyma się w przyszłości i w roku 2020 w Polsce na 100 dzieci przypadać będzie 127 osób starszych (w miastach i na wsi odpowiednio 148 i 100 osób).

W rozpatrywanym okresie, na skutek postępu procesu demograficznego starzenia się populacji, wzrosła także mediana wieku ludności, przy czym wyższe jej wartości obserwowane były w miastach. W roku 1990 wiek środkowy mężczyzn w Polsce wynosił 31 lat, a kobiet 34 lata, natomiast w roku 2014 mediana wieku mężczyzn i kobiet wyniosła odpowiednio 38 lat i 41 lat. Można oczekiwać, że w roku 2020 wiek środkowy zarówno Polaków, jak i Polek wzrośnie o 2 lata, osiągając odpowiednio wartości 40 i 43 lata.

\section{Regionalne zróżnicowanie zaawansowania starości demograficznej w Polsce w latach 2002, 2014 i 2020}

Zaawansowanie starości demograficznej w Polsce jest znacznie zróżnicowane terytorialnie, również w przekroju miasto-wieś. W 2002 roku w większości województw zaawansowanie to było wyższe na obszarach wiejskich, obecnie zaś w niemalże wszystkich tych jednostkach (z wyjątkiem podlaskiego i lubelskiego) starsze są miasta i prawdopodobnie tendencja ta utrzyma się w przyszłości (zob. tab. 1). Starość demograficzna miast, wyższa niż obszarów wiejskich, wynika przede wszystkim z relatywnie niższego poziomu dzietności, a także często ujemnego salda migracji (obecnie w Polsce obserwowana jest tendencja zasiedlania przez ludność obszarów wiejskich zlokalizowanych wokół dużych miast).

W 2014 roku najwyższym odsetkiem ludności w wieku 65+ legitymowało się województwo łódzkie (17,1\%) i świętokrzyskie (16,6\%), najniższym zaś warmińsko-mazurskie $(13,4 \%)$, lubuskie, pomorskie i wielkopolskie $(14,1 \%)$. Należy zaznaczyć, że w przypadku miast najstarsze było województwo łódzkie, najmłodsze zaś podlaskie, a w przypadku wsi podlaskie było jednostką najstarszą demograficznie, natomiast pomorskie najmłodszą (zob. tab. 1). W roku 2020 najwyższym zaawansowaniem starości demograficznej nadal legitymować się będzie województwo łódzkie, a także świętokrzyskie, dolnośląskie i śląskie, gdzie co piąta osoba będzie w wieku 65+.

Bardziej szczegółowa analiza na poziomie powiatów i gmin wskazuje, że obecnie, podobnie jak w 2002 roku, relatywnie niskim zaawansowaniem starości demograficznej charakteryzują się obszary Polski północnej, zachodniej oraz południowej, natomiast najstarsze demograficznie obszary zlokalizowane są we wschodniej części kraju, głównie w województwach podlaskim i lubelskim (zob. rys. 5-7). 
Tabela 1. Udział ludności w wieku 65+ w Polsce i w województwach w latach 2002, 2014 i 2020 (w \%)

\begin{tabular}{|l|c|c|c|c|c|c|c|c|c|}
\cline { 2 - 10 } \multicolumn{1}{c|}{} & \multicolumn{3}{c|}{$\mathbf{2 0 0 2}$} & \multicolumn{3}{c|}{$\mathbf{2 0 1 4}$} & \multicolumn{3}{c|}{$\mathbf{2 0 2 0}$} \\
\cline { 2 - 11 } \multicolumn{1}{c|}{} & Ogółem & Miasto & Wieś & Ogółem & Miasto & Wieś & Ogółem & Miasto & Wieś \\
\hline Polska & 12,8 & 12,3 & 13,5 & 15,3 & 16,3 & 13,6 & 18,9 & 20,8 & 16,1 \\
\hline Dolnośląskie & 13,0 & 13,1 & 12,7 & 15,5 & 16,9 & 12,4 & 20,0 & 21,8 & 15,9 \\
\hline $\begin{array}{l}\text { Kujawsko- } \\
\text {-Pomorskie }\end{array}$ & 11,9 & 11,9 & 11,8 & 14,7 & 16,2 & 12,4 & 18,5 & 20,8 & 15,2 \\
\hline Lubelskie & 13,9 & 10,8 & 16,7 & 15,9 & 15,7 & 16,0 & 19,3 & 20,8 & 18,1 \\
\hline Lubuskie & 11,3 & 11,1 & 11,7 & 14,1 & 15,2 & 12,1 & 18,5 & 20,2 & 15,6 \\
\hline Łódzkie & 14,7 & 13,9 & 16,1 & 17,1 & 17,8 & 15,8 & 20,9 & 22,6 & 18,0 \\
\hline Małopolskie & 12,8 & 12,9 & 12,7 & 14,9 & 16,7 & 13,1 & 17,7 & 20,5 & 15,1 \\
\hline Mazowieckie & 14,2 & 14,0 & 14,7 & 15,8 & 16,7 & 14,1 & 19,0 & 20,4 & 16,4 \\
\hline Opolskie & 12,5 & 11,6 & 13,5 & 15,9 & 16,8 & 14,8 & 19,6 & 21,6 & 17,3 \\
\hline Podkarpackie & 12,4 & 10,7 & 13,5 & 14,5 & 15,0 & 14,1 & 17,6 & 19,9 & 16,0 \\
\hline Podlaskie & 14,0 & 10,8 & 18,6 & 15,7 & 14,4 & 17,7 & 18,6 & 18,4 & 18,9 \\
\hline Pomorskie & 11,3 & 12,2 & 9,4 & 14,1 & 16,3 & 10,0 & 17,7 & 20,6 & 12,8 \\
\hline Śląskie & 12,2 & 11,9 & 13,1 & 16,1 & 16,5 & 14,4 & 20,0 & 20,8 & 17,1 \\
\hline $\begin{array}{l}\text { Świętokrzy- } \\
\text { skie }\end{array}$ & 14,4 & 12,3 & 16,2 & 16,6 & 17,5 & 15,9 & 20,5 & 23,1 & 18,4 \\
\hline $\begin{array}{l}\text { Warmińsko- } \\
\text {-Mazurskie }\end{array}$ & 11,0 & 10,9 & 11,2 & 13,4 & 14,6 & 11,8 & 17,4 & 19,4 & 14,6 \\
\hline Wielkopolskie & 11,6 & 11,7 & 11,4 & 14,1 & 15,8 & 12,0 & 17,5 & 20,0 & 14,6 \\
\hline $\begin{array}{l}\text { Zachodnio- } \\
\text { pomorskie }\end{array}$ & 11,6 & 11,9 & 11,0 & 14,6 & 16,0 & 11,6 & 19,3 & 21,3 & 15,1 \\
\hline
\end{tabular}

Źródło: GUS; opracowanie własne

W przypadku NTS4 w 2014 roku odsetek ten był najniższy w położonym w województwie zachodniopomorskim powiecie polickim (9,7\%), a także w powiatach województwa pomorskiego - kartuskim i gdańskim (10,1\%), najwyższy zaś w Sopocie (23,5\%), powiatach hajnowskim i bielskim (odpowiednio 22,3\% i 20,5\%), a także w Łodzi (20\%), (zob. rys. 5).

W przypadku NTS5 odsetek ten był najniższy w gminach województwa zachodniopomorskiego (najniższy w Kołbaskowie i Dobrej, tj. gminach wiejskich położonych w powiecie polickim, gdzie w 2014 roku odsetek ten wyniósł odpowiednio 7,1\% i 7,9\%), a także w gminach województwa pomorskiego (najniższy w Redzie - 8,1\%), oraz w Miedźnej-gminie wiejskiej położonej w powiecie pszczyńskim województwa śląskiego (7,5\%) i Łęcznej - gminie wiejsko-miejskiej zlokalizowanej w powiecie łęczyńskim województwa lubelskiego (7,8\%). Natomiast najstarsze demograficznie gminy zlokalizowane były w województwie podlaskim. W 2014 roku w dwudziestu trzech gminach tego województwa udział ludności starszej wynosił co najmniej $20 \%$ - były to gminy wiejskie położone w powiatach hajnowskim, bielskim, siemiatyckim, sokólskim i białostockim (we wsiach Bielsk Podlaski, Czyże, Orla oraz Dubicze Cerkiewne 
odsetek ten kształtował się w granicach 32-39,8\%, przy czym najwyższy był w ostatniej z wymienionych miejscowości). Wysokim zaawansowaniem starości demograficznej legitymowały się również obszary Polski Centralnej, w szczególności zlokalizowane w województwach łódzkim i świętokrzyskim (zob. rys. 6).

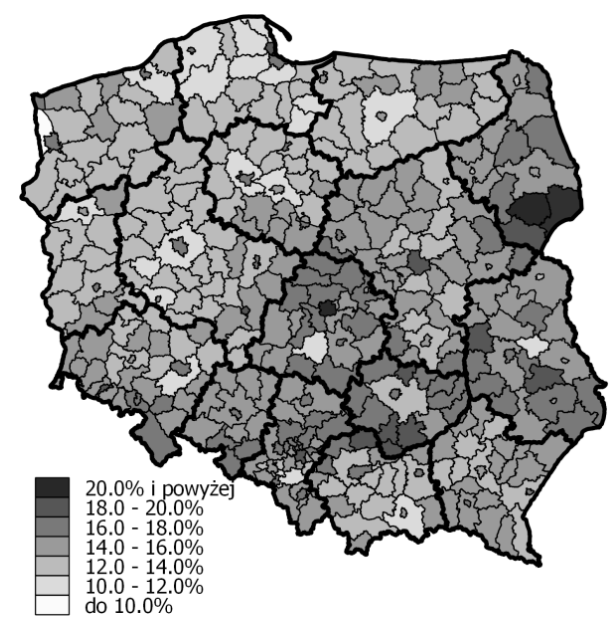

Rysunek 5. Odsetek ludności w wieku 65+ w powiatach w 2014 roku Źródło: GUS; opracowanie własne

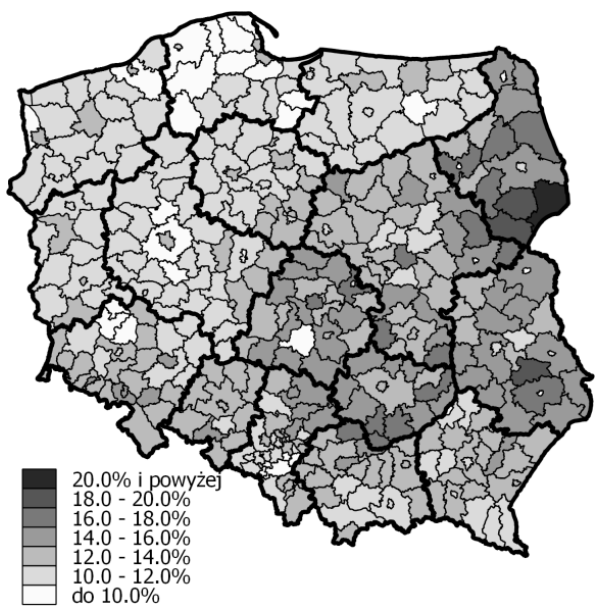

Rysunek 7. Odsetek ludności w wieku 65+ w powiatach w 2002 roku

Źródło: GUS; opracowanie własne

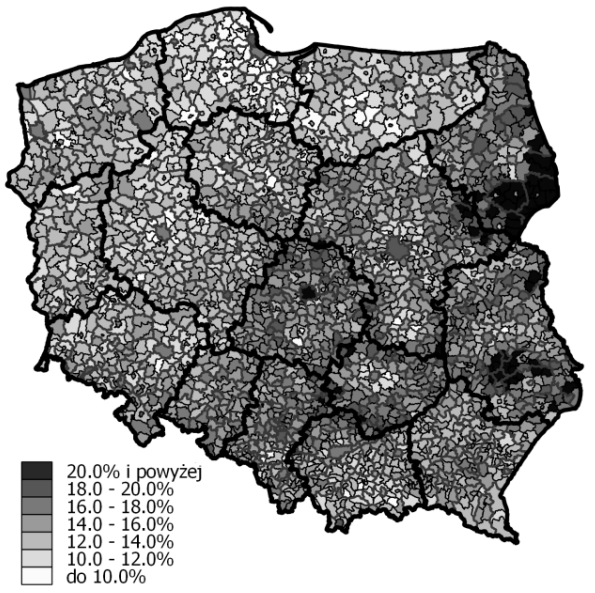

Rysunek 6. Odsetek ludności w wieku 65+ w gminach w 2014 roku Źródło: GUS; opracowanie własne

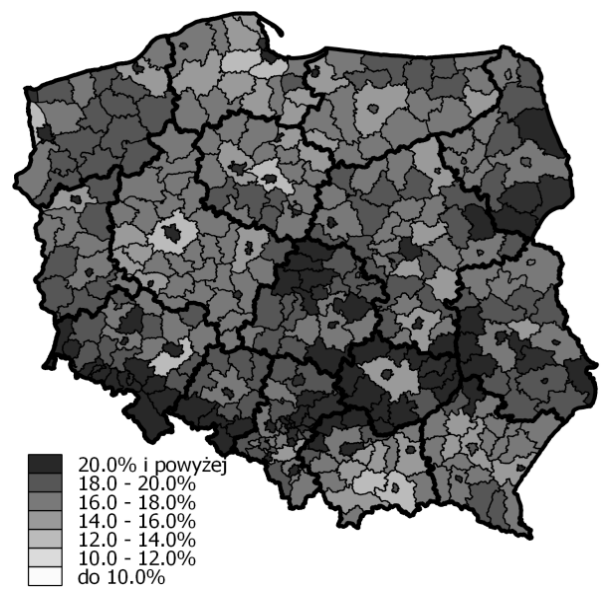

Rysunek 8. Odsetek ludności w wieku 65+ w powiatach w 2020 roku Źródło: GUS; opracowanie własne

W perspektywie kolejnych kilku lat należy oczekiwać dalszego postępu procesu starzenia się, kiedy to w 2020 roku w niektórych powiatach centralnej i wschod- 
niej części Polski odsetek ludności w wieku 65+ prawdopodobnie przekroczy 22\% (zob. rys. 8). Najwyższa wartość tego miernika zostanie odnotowana w Sopocie $(27,1 \%)$ oraz w powiecie hajnowskim $(25,9 \%)$, a także w Jeleniej Górze, Łodzi i Sosnowcu (24-25,2\%). Ponadto relatywnie wysokim udziałem subpopulacji seniorów charakteryzować się będą miasta, zwłaszcza duże. Natomiast względnie najniższy odsetek osób w wieku 65+ odnotowany zostanie w powiatach kartuskim (12\%), gdańskim (12,7\%), a także nowosądeckim, toruńskim i wrocławskim $(13,4-13,5 \%)$.

W Polsce obserwowany jest także stopniowy wzrost udziału ludności sędziwej, tj. będącej w wieku 80+. W 2014 roku odsetek ten wyniósł 4\% (w miastach i na wsi odpowiednio 4,1\% i 3,9\%) i był wyższy od wartości odnotowanej w 2002 roku o 1,8 p.p. (w miastach i na wsi odpowiednio o 2 p.p. i 1,4 p.p.). W perspektywie kolejnych kilku lat należy oczekiwać dalszego wzrostu rozpatrywanej frakcji, tak że w roku 2020 jej udział prawdopodobnie wyniesie $4,4 \%$ (zob. tab. 2).

Tabela 2. Udział ludności w wieku 80+ w Polsce i w województwach w latach 2002, 2014 i 2020 (w \%)

\begin{tabular}{|l|c|c|c|c|c|c|c|c|c|}
\cline { 2 - 11 } \multicolumn{1}{c|}{} & \multicolumn{3}{c|}{$\mathbf{2 0 0 2}$} & \multicolumn{3}{c|}{$\mathbf{2 0 1 4}$} & \multicolumn{3}{c|}{$\mathbf{2 0 2 0}$} \\
\cline { 2 - 11 } \multicolumn{1}{c|}{} & Ogółem & Miasto & Wieś & Ogółem & Miasto & Wieś & Ogółem & Miasto & Wieś \\
\hline Polska & 2,2 & 2,1 & 2,5 & 4,0 & 4,1 & 3,9 & 4,4 & 4,7 & 3,9 \\
\hline Dolnośląskie & 2,0 & 1,9 & 2,3 & 4,1 & 4,4 & 3,5 & 4,4 & 4,9 & 3,3 \\
\hline $\begin{array}{l}\text { Kujawsko- } \\
\text {-Pomorskie }\end{array}$ & 2,2 & 2,1 & 2,2 & 3,6 & 3,9 & 3,3 & 4,0 & 4,5 & 3,4 \\
\hline Lubelskie & 2,6 & 1,8 & 3,3 & 4,4 & 3,7 & 5,0 & 4,7 & 4,4 & 5,0 \\
\hline Lubuskie & 1,8 & 1,7 & 2,1 & 3,5 & 3,6 & 3,2 & 3,8 & 4,2 & 3,1 \\
\hline Lódzkie & 2,8 & 2,5 & 3,3 & 4,5 & 4,5 & 4,5 & 4,7 & 4,9 & 4,5 \\
\hline Małopolskie & 2,3 & 2,2 & 2,3 & 4,0 & 4,3 & 3,6 & 4,5 & 5,1 & 3,9 \\
\hline Mazowieckie & 2,6 & 2,5 & 3,0 & 4,5 & 4,6 & 4,2 & 4,7 & 5,0 & 4,1 \\
\hline Opolskie & 1,9 & 1,7 & 2,1 & 4,0 & 3,9 & 4,1 & 4,9 & 5,0 & 4,8 \\
\hline Podkarpackie & 2,2 & 1,7 & 2,5 & 3,9 & 3,7 & 4,1 & 4,4 & 4,5 & 4,4 \\
\hline Podlaskie & 2,6 & 1,8 & 3,6 & 4,7 & 3,7 & 6,1 & 5,1 & 4,5 & 6,0 \\
\hline Pomorskie & 1,9 & 2,1 & 1,6 & 3,5 & 4,0 & 2,5 & 4,0 & 4,7 & 2,6 \\
\hline Śląskie & 2,0 & 1,9 & 2,3 & 3,7 & 3,8 & 3,7 & 4,6 & 4,8 & 4,2 \\
\hline $\begin{array}{l}\text { Świętokrzy- } \\
\text { skie }\end{array}$ & 2,7 & 2,0 & 3,3 & 4,6 & 4,2 & 4,9 & 5,0 & 5,2 & 4,9 \\
\hline $\begin{array}{l}\text { Warmińsko- } \\
\text {-Mazurskie }\end{array}$ & 1,7 & 1,7 & 1,7 & 3,5 & 3,7 & 3,2 & 3,9 & 4,2 & 3,4 \\
\hline Wielkopolskie & 2,2 & 2,2 & 2,2 & 3,4 & 3,7 & 3,0 & 3,7 & 4,3 & 3,1 \\
\hline $\begin{array}{l}\text { Zachodnio- } \\
\text { pomorskie }\end{array}$ & 1,7 & 1,7 & 1,8 & 3,6 & 3,9 & 3,1 & 4,0 & 4,5 & 3,0 \\
\hline
\end{tabular}


W 2014 roku najwyższy odsetek ludności sędziwej odnotowany został w województwie podlaskim i świętokrzyskim, najniższy zaś w wielkopolskim (zob. tab. 2). Wymienione województwa legitymować się będą odpowiednio najwyższym i najniższym udziałem ludności w wieku 80+ również w roku 2020.

Rozpatrując jednostki NTS4, można stwierdzić, że w 2014 roku najwyższym odsetkiem omawianej subpopulacji charakteryzowały się powiaty hajnowski (7,5\%) i bielski (7\%) oraz miasto Sopot (7,3\%), najniższym zaś Żory $(1,8 \%)$ oraz powiat policki (2\%), a także Jastrzębie-Zdrój i powiaty: gdański, pucki, poznański, kartuski, wejherowski, głogowski (gdzie odsetek ten kształtował się w granicach $2,2-2,5 \%)$.

Tabela 3. Wartości indeksu starości $\left(L_{65+} / L_{0-14}\right)$ w Polsce i w województwach w latach 2002, 2014 i 2020

\begin{tabular}{|l|c|c|c|c|c|c|c|c|c|}
\cline { 2 - 10 } \multicolumn{1}{c|}{} & \multicolumn{3}{c|}{$\mathbf{2 0 0 2}$} & \multicolumn{3}{c|}{$\mathbf{2 0 1 4}$} & \multicolumn{3}{c|}{$\mathbf{2 0 2 0}$} \\
\cline { 2 - 11 } \multicolumn{1}{l|}{} & Ogółem & Miasto & Wieś & Ogółem & Miasto & Wieś & Ogółem & Miasto & Wieś \\
\hline Polska & 0,72 & 0,78 & 0,65 & 1,02 & 1,17 & 0,83 & 1,27 & 1,48 & 1,00 \\
\hline Dolnośląskie & 0,80 & 0,88 & 0,65 & 1,11 & 1,28 & 0,78 & 1,42 & 1,63 & 1,04 \\
\hline $\begin{array}{l}\text { Kujawsko- } \\
\text {-Pomorskie }\end{array}$ & 0,64 & 0,72 & 0,55 & 0,97 & 1,17 & 0,73 & 1,25 & 1,53 & 0,92 \\
\hline Lubelskie & 0,75 & 0,63 & 0,83 & 1,07 & 1,13 & 1,03 & 1,35 & 1,55 & 1,20 \\
\hline Lubuskie & 0,62 & 0,66 & 0,56 & 0,93 & 1,05 & 0,74 & 1,24 & 1,41 & 0,98 \\
\hline Łódzkie & 0,91 & 0,96 & 0,84 & 1,22 & 1,36 & 1,02 & 1,50 & 1,73 & 1,17 \\
\hline Małopolskie & 0,68 & 0,82 & 0,57 & 0,94 & 1,20 & 0,75 & 1,13 & 1,45 & 0,89 \\
\hline Mazowieckie & 0,84 & 0,94 & 0,71 & 1,01 & 1,12 & 0,84 & 1,20 & 1,32 & 1,00 \\
\hline Opolskie & 0,73 & 0,72 & 0,75 & 1,20 & 1,32 & 1,09 & 1,53 & 1,76 & 1,31 \\
\hline Podkarpackie & 0,61 & 0,60 & 0,62 & 0,94 & 1,06 & 0,87 & 1,20 & 1,45 & 1,04 \\
\hline Podlaskie & 0,74 & 0,59 & 0,93 & 1,09 & 1,02 & 1,18 & 1,33 & 1,34 & 1,32 \\
\hline Pomorskie & 0,60 & 0,75 & 0,39 & 0,86 & 1,11 & 0,52 & 1,09 & 1,40 & 0,68 \\
\hline Śląskie & 0,75 & 0,77 & 0,70 & 1,14 & 1,22 & 0,93 & 1,41 & 1,52 & 1,11 \\
\hline $\begin{array}{l}\text { Świętokrzy- } \\
\text { skie }\end{array}$ & 0,81 & 0,79 & 0,82 & 1,19 & 1,38 & 1,07 & 1,52 & 1,89 & 1,28 \\
\hline $\begin{array}{l}\text { Warmińsko- } \\
\text {-Mazurskie }\end{array}$ & 0,56 & 0,62 & 0,50 & 0,87 & 1,02 & 0,69 & 1,16 & 1,38 & 0,89 \\
\hline Wielkopolskie & 0,62 & 0,71 & 0,53 & 0,88 & 1,08 & 0,68 & 1,10 & 1,37 & 0,83 \\
\hline $\begin{array}{l}\text { Zachodnio- } \\
\text { pomorskie }\end{array}$ & 0,65 & 0,74 & 0,50 & 1,01 & 1,19 & 0,70 & 1,37 & 1,60 & 0,95 \\
\hline
\end{tabular}

Źródło: GUS; opracowanie własne

Jak już wspominano, obserwowane przemiany w liczebnościach subpopulacji dzieci (0-14 lat) i osób starszych (65+) znalazły odzwierciedlenie w zmianach wartości indeksu starości. Analizując terytorialne zróżnicowanie tego miernika, można stwierdzić, że na początku bieżącego stulecia wszystkie województwa legitymowały się liczebną przewagą dzieci nad subpopulacją osób starszych, 
zarówno w miastach, jak i na wsi (zob. tab. 3). Na przestrzeni lat 2002-2014 wartości tego miernika wzrosły we wszystkich tych jednostkach i w 2014 roku w większości z nich frakcja osób starszych przeważała liczebnie nad subpopulacją dzieci. W 2014 roku największą przewagą osób starszych legitymowało się województwo łódzkie (gdzie na 100 dzieci w wieku 0-14 lat przypadały 122 osoby w wieku 65+), największą przewagą dzieci zaś pomorskie (gdzie na 100 dzieci przypadało 86 osób starszych). W 2014 roku we wszystkich województwach $\mathrm{z}$ wyjątkiem podlaskiego miernik ten osiągnął wyższe wartości w miastach (zob. tab. 3). W roku 2020 na obszarach wiejskich siedmiu województw obserwowana będzie przewaga młodszej z rozpatrywanych subpopulacji (najwyższa w pomorskim), na pozostałych zaś, podobnie jak w miastach wszystkich województw, frakcja osób starszych będzie liczebnie przeważać nad dziećmi (zob. tab. 5).

Biorąc pod uwagę jednostki NTS4, można zauważyć, że w Polsce północnej, zachodniej i południowej dominują obszary przewagi liczebnej dzieci (0-14 lat) nad osobami starszymi (65+) - największe w powiecie kartuskim, gdzie w 2014 roku na 100 dzieci przypadało statystycznie 47 osób starszych, a także w powiatach gdańskim, wejherowskim, polickim i poznańskim (54-59 osób). Największą zaś liczebną przewagą osób starszych nad dziećmi w roku 2014 legitymował się Sopot (230 osób), a także powiat hajnowski (195 osób), Łódź (167 osób) oraz Jelenia Góra i Katowice (159 osób) (zob. rys. 10).

W przypadku jednostek NTS5 omawiany miernik osiągnął najniższe wartości w gminach wiejskich województw pomorskiego i zachodniopomorskiego, w szczególności w Luzinie, Kołbaskowie, Dopiewie, Sierakowicach, Komornikach i Kleszczewie (gdzie w 2014 roku na 100 dzieci przypadało 36-38 osób starszych), najwyższe zaś w gminach województwa podlaskiego - tj. we wsiach Dubicze Cerkiewne, Czyże i Orla (gdzie iloraz ten wynosił odpowiednio 487, 377 i 344 osób) oraz w Mielniku, Białowieży, Narwi, Milejczycach, Kleszczelach i Bielsku Podlaskim (240-290 osób). Znaczną przewagą starszej z tych frakcji legitymował się także Sopot (230 osób).

Na początku bieżącego stulecia indeks starości osiągał znacznie niższe wartości niż obecnie (zob. rys. 9). Wówczas w najstarszych demograficznie powiatach, tj. hajnowskim i Sopocie, na 100 dzieci przypadały odpowiednio 137 i 163 osoby starsze. Iloraz ten był także relatywnie wysoki w Łodzi i Warszawie (135 osób) oraz we Wrocławiu (116 osób). Natomiast najniższe wartości tego miernika zostały odnotowane w Żorach (gdzie na 100 dzieci przypadały 32 osoby w wieku 65+), a także w powiecie kartuskim, polickim i w Jastrzębiu-Zdroju (36-39 osób).

Natomiast w roku $2020 \mathrm{w}$ większości powiatów obserwowana będzie liczebna przewaga osób starszych nad frakcją dzieci - największa w Sopocie (gdzie na 100 dzieci przypadać będą 243 osoby w wieku 65+) i w powiecie hajnowskim (240 osób), a także w Jeleniej Górze (214 osób) oraz w Sosnowcu, Wałbrzychu, Świnoujściu i w Łodzi (203-205 osób). Liczebną przewagą dzieci nad osobami 
starszymi legitymować się będą powiaty w województwie pomorskim (największą kartuski i gdański, gdzie indeks starości wyniesie odpowiednio 0,57 i 0,68), małopolskim oraz obrzeża większości dużych miast (zob. rys. 11).

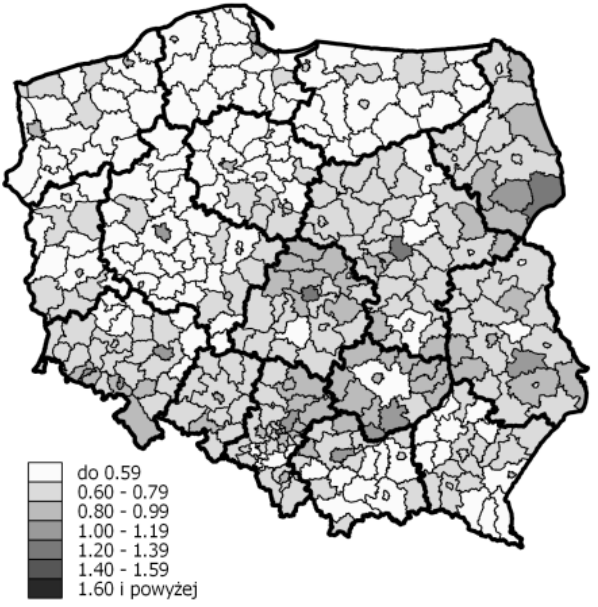

Rysunek 9. Wartości indeksu starości w powiatach w 2002 roku Źródło: GUS; opracowanie własne

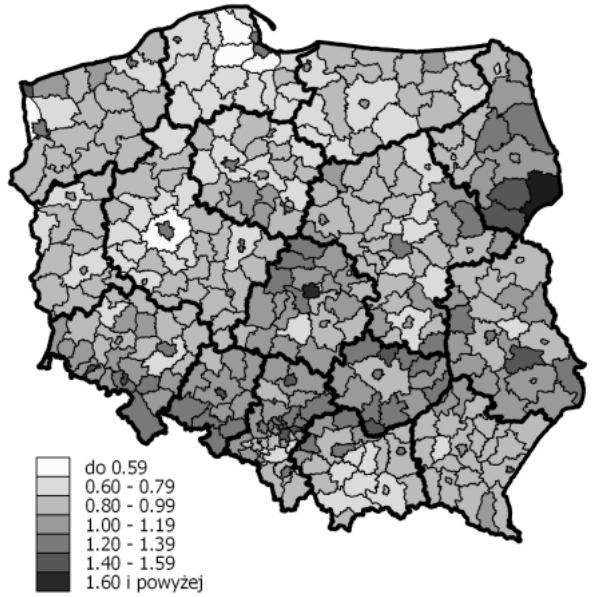

Rysunek 10. Wartości indeksu starości w powiatach w 2014 roku Źródło: GUS; opracowanie własne

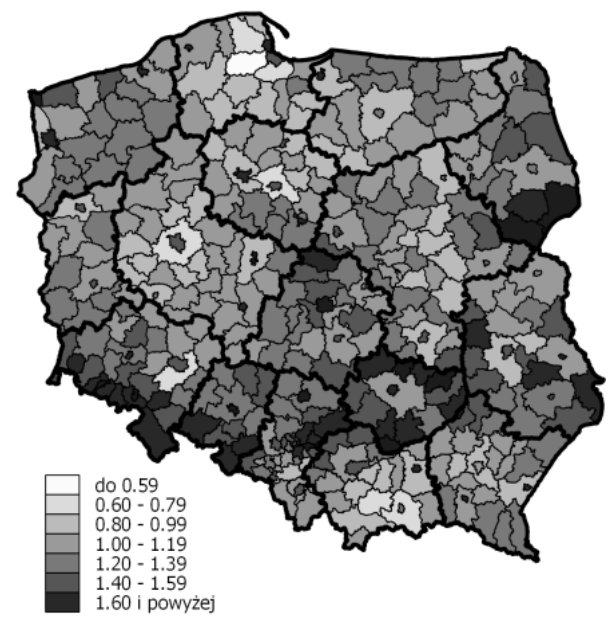

Rysunek 11. Wartości indeksu starości w powiatach w 2020 roku Źródło: GUS; opracowanie własne

W Polsce na skutek postępu starości demograficznej wzrasta także wartość współczynnika obciążenia demograficznego osobami starszymi, wyrażonego ilorazem liczebności osób w wieku 65+ do liczby ludności w wieku 15-64 lata. W 2014 roku w Polsce na 100 osób w wieku 15-64 lata przypadały 22 osoby star- 
sze (w miastach i na wsi odpowiednio 23 i 20), w 2002 roku 18 osób (w miastach i na wsi odpowiednio 17 i 21), w roku 2020 prawdopodobnie przypadać będzie 28 osób (w miastach i na wsi odpowiednio 32 i 24 osoby).

Spośród województw w 2014 roku współczynnik ten osiągnął najwyższą wartość w województwie łódzkim i świętokrzyskim, najniższą zaś w warmińsko-mazurskim (zob. tab. 4). W perspektywie kolejnych lat należy oczekiwać dalszego wzrostu tego współczynnika we wszystkich województwach, w następstwie czego w 2020 roku w łódzkim na 100 osób w wieku 15-64 lata przypadać będą 32 osoby w wieku 65+.

Tabela 4. Wartości współczynnika obciążenia demograficznego osobami starszymi $\left(L_{65+} / L_{15-64}\right)$ w Polsce i w województwach w latach 2002, 2014 i 2020

\begin{tabular}{|l|c|c|c|c|c|c|c|c|c|}
\cline { 2 - 10 } \multicolumn{1}{c|}{} & \multicolumn{3}{c|}{$\mathbf{2 0 0 2}$} & \multicolumn{3}{c|}{$\mathbf{2 0 1 4}$} & \multicolumn{3}{c|}{$\mathbf{2 0 2 0}$} \\
\cline { 2 - 11 } \multicolumn{1}{l|}{} & Ogólem & Miasto & Wieś & Ogólem & Miasto & Wieś & Ogółem & Miasto & Wieś \\
\hline Polska & 0,18 & 0,17 & 0,21 & 0,22 & 0,23 & 0,20 & 0,28 & 0,32 & 0,24 \\
\hline Dolnośląskie & 0,18 & 0,18 & 0,19 & 0,22 & 0,24 & 0,17 & 0,30 & 0,34 & 0,23 \\
\hline $\begin{array}{l}\text { Kujawsko- } \\
\text {-Pomorskie }\end{array}$ & 0,17 & 0,17 & 0,18 & 0,21 & 0,23 & 0,18 & 0,28 & 0,32 & 0,22 \\
\hline Lubelskie & 0,21 & 0,15 & 0,26 & 0,23 & 0,22 & 0,23 & 0,29 & 0,32 & 0,27 \\
\hline Lubuskie & 0,16 & 0,15 & 0,17 & 0,20 & 0,22 & 0,17 & 0,28 & 0,31 & 0,23 \\
\hline Łódzkie & 0,21 & 0,19 & 0,25 & 0,25 & 0,26 & 0,23 & 0,32 & 0,35 & 0,27 \\
\hline Małopolskie & 0,19 & 0,18 & 0,20 & 0,21 & 0,24 & 0,19 & 0,26 & 0,31 & 0,22 \\
\hline Mazowieckie & 0,21 & 0,20 & 0,23 & 0,23 & 0,24 & 0,20 & 0,29 & 0,32 & 0,24 \\
\hline Opolskie & 0,18 & 0,16 & 0,20 & 0,22 & 0,24 & 0,21 & 0,29 & 0,33 & 0,25 \\
\hline Podkarpackie & 0,18 & 0,15 & 0,21 & 0,21 & 0,21 & 0,20 & 0,26 & 0,30 & 0,23 \\
\hline Podlaskie & 0,21 & 0,15 & 0,30 & 0,22 & 0,20 & 0,26 & 0,28 & 0,27 & 0,28 \\
\hline Pomorskie & 0,16 & 0,17 & 0,14 & 0,20 & 0,24 & 0,14 & 0,27 & 0,32 & 0,19 \\
\hline Śląskie & 0,17 & 0,16 & 0,19 & 0,23 & 0,24 & 0,21 & 0,30 & 0,32 & 0,25 \\
\hline $\begin{array}{l}\text { Świętokrzy- } \\
\text { skie }\end{array}$ & 0,21 & 0,17 & 0,25 & 0,24 & 0,25 & 0,23 & 0,31 & 0,36 & 0,27 \\
\hline $\begin{array}{l}\text { Warmińsko- } \\
\text {-Mazurskie }\end{array}$ & 0,16 & 0,15 & 0,17 & 0,19 & 0,21 & 0,17 & 0,26 & 0,29 & 0,21 \\
\hline Wielkopolskie & 0,17 & 0,16 & 0,17 & 0,20 & 0,23 & 0,17 & 0,26 & 0,31 & 0,22 \\
\hline $\begin{array}{l}\text { Zachodnio- } \\
\text { pomorskie }\end{array}$ & 0,16 & 0,16 & 0,16 & 0,21 & 0,23 & 0,16 & 0,29 & 0,32 & 0,22 \\
\hline
\end{tabular}

Źródło: GUS; opracowanie własne

Biorąc pod uwagę mniejsze jednostki administracyjne, można stwierdzić, że obecnie relatywnie wysokimi wartościami tego wskaźnika charakteryzuje się Sopot (gdzie w 2014 roku na 100 osób w wieku 15-64 lata przypadało statystycznie 35 osób w wieku 65+), a także obszary Polski wschodniej i centralnej (zob. rys. 13), a najwyższymi jednostki województwa podlaskiego (w powiatach siemiatyckim, bielskim i hajnowskim współczynnik ten wyniósł odpowiednio 28, 31 i 35, natomiast w położonych w tym województwie gminach Dubicze Cerkiewne, Orla 
i Czyże osiągnął wartości wynoszące odpowiednio 75, 71 i 64). Relatywnie najniższymi wartościami współczynnika obciążenia demograficznego legitymowały się powiaty: policki, kartuski, gdański i toruński (gdzie w 2014 roku na 100 osób w wieku 15-64 lata przypadało statystycznie 13-15 osób w wieku 65+).

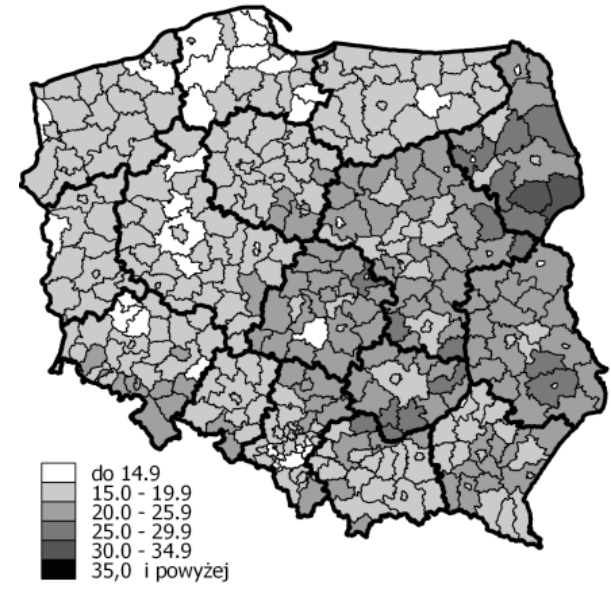

Rysunek 12. Wartości współczynnika obciążenia osobami starszymi w powiatach w 2002 roku Źródło: GUS; opracowanie własne

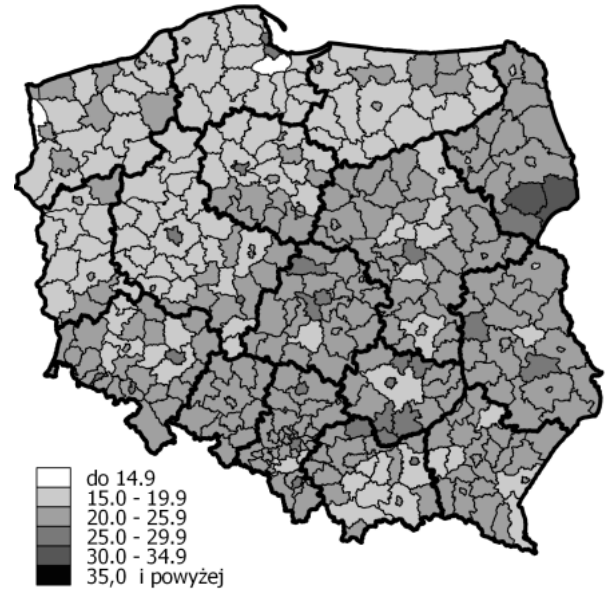

Rysunek 13. Wartości współczynnika obciążenia osobami starszymi w powiatach w 2014 roku Źródło: GUS; opracowanie własne

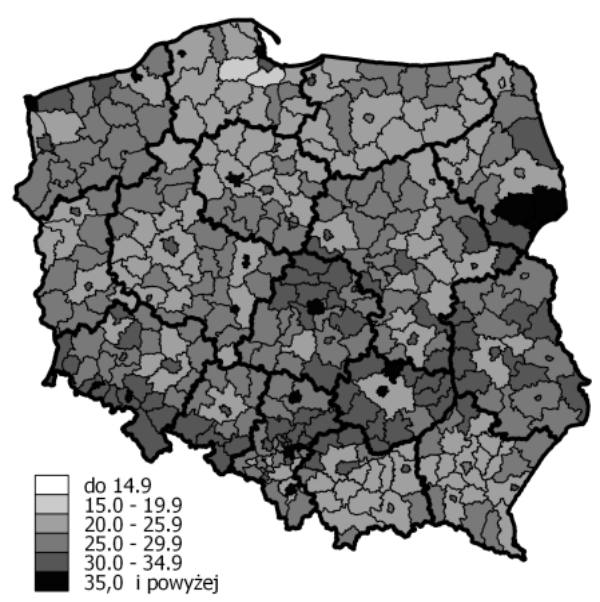

Rysunek 14. Wartości współczynnika obciążenia osobami starszymi w powiatach w 2020 roku

Źródło: GUS; opracowanie własne

Jak już wspomniano, w roku 2002 obciążenie grupy wiekowej 15-64 lata frakcją osób starszych było znacznie mniejsze niż jest obecnie (zob. rys. 12) - najwyż- 
sze wystąpiło we wschodniej części Polski (w powiatach hajnowskim i bielskim na 100 osób w wieku 15-64 lata przypadało odpowiednio 32 i 30 osób w wieku 65+), najniższe zaś w Żorach (7 osób). W roku 2020 należy spodziewać się dalszego wzrostu wartości tego współczynnika (zob. rys. 14). Najwyższe jego wartości prawdopodobnie zostaną odnotowane w Sopocie (gdzie na 100 osób w wieku 15-64 lata przypadać będą 44 osoby w wieku 65+), a także w Łodzi, Jeleniej Górze i powiecie hajnowskim (39-41 osób), najniższe zaś w powiatach kartuskim i gdańskim (odpowiednio 18 i 19 osób).

\section{Dynamika procesu starzenia się populacji w Polsce w latach 2002-2020}

W latach 2002-2014 odsetek osób starszych w Polsce zwiększył się o 19\% (w miastach i na wsi odpowiednio o $32 \%$ i $1 \%$, co świadczy o zróżnicowanym tempie postępu procesu starzenia się mieszkańców miast i wsi). Według prognoz GUS w latach 2014-2020 odsetek ludności starszej w Polsce wzrośnie o 24\%, natomiast w okresie 2002-2020 należy się spodziewać wzrostu omawianej frakcji o $47 \%$ (zob. tab. 5).

W przekroju województw w latach 2002-2014 wzrost udziału osób starszych w populacji był najwyższy w śląskim (o 32\%), najniższy zaś w mazowieckim (o 11\%), natomiast niewielkie „odmłodzenie” populacji w tym okresie (rzędu 2-5\%) zostało odnotowane na obszarach wiejskich w sześciu województwach (zob. tab. 5). W latach 2014-2020, podobnie jak w okresie 2002-2020, najwyższego wzrostu odsetka seniorów należy spodziewać się w województwie zachodniopomorskim.

W przypadku jednostek NTS4 w latach 2002-2014 najwyższym wzrostem omawianej frakcji (powyżej 20\%) charakteryzowała się większość miast powiatowych (zob. rys. 15), przy czym wzrost ten był najwyższy w Jastrzębiu-Zdroju (o 133\%) oraz w Żorach (o 116\%), Tarnobrzegu (o 77\%) i Koninie (o 75\%). Wynikał on głównie z silnego odpływu migracyjnego ludności z młodych grup wiekowych w tych jednostkach. Spośród stolic województw dynamika procesu starzenia się populacji była największa w Opolu i Kielcach (odpowiednio 47\% i 49\%), najniższa zaś w Warszawie (12\%) i we Wrocławiu (19\%). Natomiast „odmłodzeniem” populacji w tym okresie charakteryzowało się łącznie 13 powiatów, największym łomżyński, chełmski, ostrołęcki, skierniewicki i siedlecki (gdzie odnotowano spadek liczebności omawianej frakcji o 6-8\%).

W okresie 2014-2020 we wszystkich powiatach odnotowany zostanie wzrost udziału ludności starszej, przy czym będzie on wyższy w zachodniej i północnej części kraju (czyli obszarach cechujących się obecnie relatywnie niskim zaawan- 
sowaniem starzenia się populacji), niższy zaś w centralnej i wschodniej części Polski (czyli obszarach o relatywnie wysokim zaawansowaniu starości demograficznej).

Tabela 5. Dynamika odsetka ludności w wieku 65+ w Polsce i w województwach w latach 2002, 2014 i 2020 (odpowiednio lata $2002=1,0$ i $2014=1,0$ )

\begin{tabular}{|l|c|c|c|c|c|c|c|c|c|}
\cline { 2 - 10 } \multicolumn{1}{c|}{} & \multicolumn{3}{c|}{$\mathbf{2 0 1 4 / 2 0 0 2}$} & \multicolumn{3}{c|}{$\mathbf{2 0 2 0 / 2 0 1 4}$} & \multicolumn{3}{c|}{$\mathbf{2 0 2 0 / 2 0 0 2}$} \\
\cline { 2 - 10 } \multicolumn{1}{c|}{} & Ogółem & Miasto & Wieś & Ogółem & Miasto & Wieś & Ogólem & Miasto & Wieś \\
\hline Polska & 1,19 & 1,32 & 1,01 & 1,24 & 1,27 & 1,18 & 1,47 & 1,68 & 1,19 \\
\hline Dolnośląskie & 1,19 & 1,29 & 0,98 & 1,29 & 1,29 & 1,28 & 1,53 & 1,67 & 1,25 \\
\hline $\begin{array}{l}\text { Kujawsko- } \\
\text {-Pomorskie }\end{array}$ & 1,24 & 1,36 & 1,05 & 1,26 & 1,28 & 1,22 & 1,56 & 1,74 & 1,29 \\
\hline Lubelskie & 1,14 & 1,45 & 0,96 & 1,22 & 1,33 & 1,13 & 1,39 & 1,93 & 1,08 \\
\hline Lubuskie & 1,25 & 1,37 & 1,04 & 1,31 & 1,33 & 1,29 & 1,63 & 1,82 & 1,33 \\
\hline Łódzkie & 1,17 & 1,28 & 0,98 & 1,22 & 1,27 & 1,14 & 1,42 & 1,63 & 1,12 \\
\hline Małopolskie & 1,16 & 1,29 & 1,03 & 1,19 & 1,22 & 1,15 & 1,38 & 1,58 & 1,18 \\
\hline Mazowieckie & 1,11 & 1,20 & 0,96 & 1,20 & 1,22 & 1,16 & 1,33 & 1,46 & 1,11 \\
\hline Opolskie & 1,27 & 1,45 & 1,09 & 1,23 & 1,28 & 1,17 & 1,56 & 1,87 & 1,28 \\
\hline Podkarpackie & 1,17 & 1,39 & 1,04 & 1,22 & 1,33 & 1,14 & 1,42 & 1,85 & 1,18 \\
\hline Podlaskie & 1,12 & 1,33 & 0,95 & 1,18 & 1,28 & 1,07 & 1,33 & 1,70 & 1,02 \\
\hline Pomorskie & 1,24 & 1,33 & 1,07 & 1,26 & 1,26 & 1,27 & 1,57 & 1,68 & 1,36 \\
\hline Śląskie & 1,32 & 1,38 & 1,10 & 1,24 & 1,26 & 1,18 & 1,64 & 1,75 & 1,30 \\
\hline $\begin{array}{l}\text { Świętokrzy- } \\
\text { skie }\end{array}$ & 1,15 & 1,42 & 0,98 & 1,23 & 1,32 & 1,16 & 1,42 & 1,87 & 1,14 \\
\hline $\begin{array}{l}\text { Warmińsko- } \\
\text {-Mazurskie }\end{array}$ & 1,22 & 1,33 & 1,05 & 1,29 & 1,33 & 1,24 & 1,58 & 1,77 & 1,30 \\
\hline Wielkopolskie & 1,22 & 1,34 & 1,06 & 1,24 & 1,27 & 1,22 & 1,52 & 1,71 & 1,29 \\
\hline $\begin{array}{l}\text { Zachodnio- } \\
\text { pomorskie }\end{array}$ & 1,26 & 1,35 & 1,06 & 1,32 & 1,32 & 1,30 & 1,67 & 1,79 & 1,38 \\
\hline
\end{tabular}

Wzrost ten prawdopodobnie będzie najwyższy w Żorach (o 60\%), a także w Ostrołęce, Białej Podlaskiej oraz w powiatach głogowskim i polickim (o 45-48\%), najniższy zaś w powiecie bielskim i skierniewickim (o 9-10\%). Natomiast w okresie 2002-2020 najsilniejszego postępu procesu starzenia się doświadczą populacje Żor (o 246\%), Jastrzębia-Zdroju (o 188\%), Tarnobrzegu i powiatu głogowskiego (o 136-137\%), najniższego zaś populacje powiatów łomżyńskiego, skierniewickiego i ostrołęckiego (o 1-3\%), (zob. rys. 17).

Postęp starzenia się populacji może być niwelowany wzrostem odsetka najmłodszej grupy wiekowej, rekompensującej zasoby subpopulacji osób starszych (szczególnie w sytuacji, gdy „kurczy się” grupa środkowa). Najczęściej ma jednak miejsce sytuacja, gdzie wzrostowi frakcji osób starszych towarzyszy spadek udziału dzieci (lub niewielki jego wzrost, nierównoważący przyrostu odsetka lud- 
ności starszej). Miernikiem uwzględniającym w czasie zmiany, zarówno frakcji dzieci, jak i osób starszych, pozwalającym ocenić dynamikę procesu starzenia się populacji, jest wskaźnik starzenia się demograficznego $W_{S D}$, zaproponowany przez Z. Długosza?.

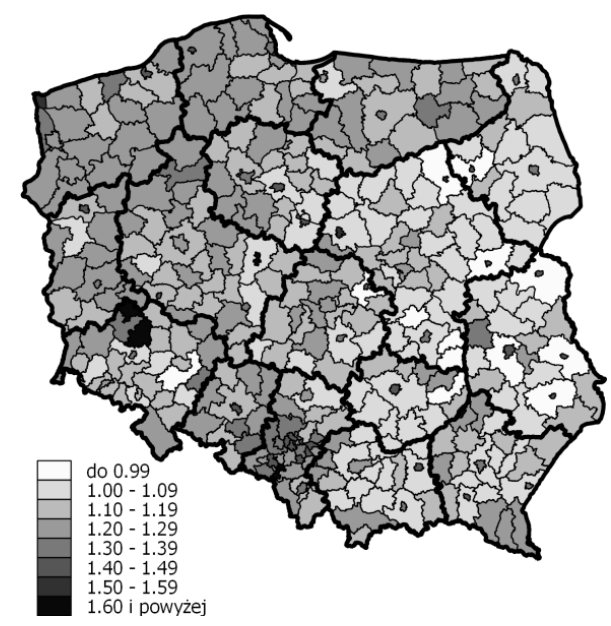

Rysunek 15. Dynamika udziałów ludności w wieku $65+$ w powiatach w latach 2002-2014 (2002 = 1,0)

Źródło: GUS; opracowanie własne

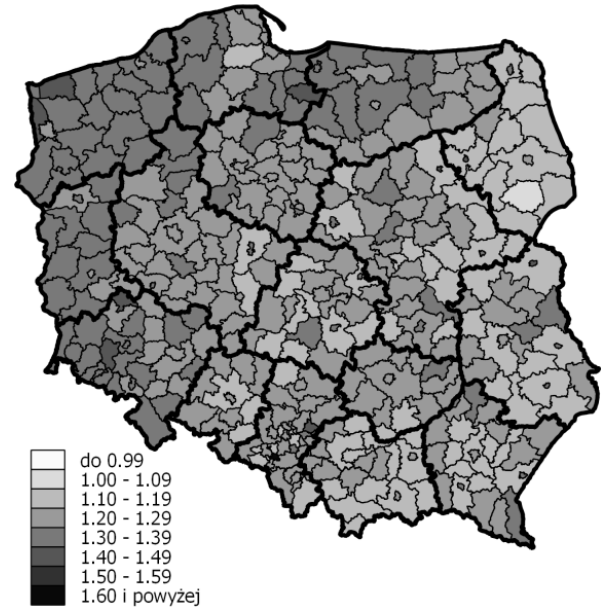

Rysunek 16. Dynamika udziałów ludności w wieku 65+ w powiatach w latach 2014-2020 $(2014=1,0)$

Źródło: GUS; opracowanie własne

Rozważając wartości tego miernika w powiatach, można stwierdzić, że w latach 2002-2014 w niemalże wszystkich jednostkach odnotowany został postęp procesu starzenia się populacji (zob. rys. 18) - najwyższy w Koninie, Tarnobrzegu i Jastrzębiu-Zdroju (gdzie wartości tego miernika wyniosły odpowiednio 11,4, 11,9 i 13,5), najniższy zaś w powiatach piaseczyńskim, wrocławskim i grodziskim $(0,5-0,6)$. Natomiast nieznaczne ,odmłodzenie” populacji (zahamowanie procesu starzenia się) w tym okresie miało miejsce w Warszawie (gdzie wskaźnik ten wyniósł $-0,2)^{8}$.

${ }^{7}$ Formuła tego wskaźnika jest następująca (Długosz, 1998: 19): $W_{S D}=\left[U_{(0-14) t}-U_{(0-14) t+n}\right]+$ $\left[U_{(65+) t+n}-U_{(65+) t}\right]$, gdzie: $W_{S D}$ - wskaźnik starzenia się demograficznego, $U_{(0-14) t}, U_{(0-14) t+n}-$ udziały ludności w wieku 0-14 lat odpowiednio na początku i na końcu badanego okresu, $U_{(65+) t+n}$, $U_{(65+) t}$ - udziały osób w wieku 65 lat i więcej odpowiednio na początku i na końcu badanego okresu. Wartości tego miernika poniżej zera świadczą o cofnięciu się procesu starzenia się (odmładzaniu się) populacji, a powyżej zera o jego postępie (im są one wyższe, tym ten postęp jest większy).

${ }^{8} \mathrm{~W}$ analizowanym okresie wartość tego miernika dla Polski wyniosła 5,3 (w miastach i na wsi odpowiednio 5,9 i 4,5$)$. 


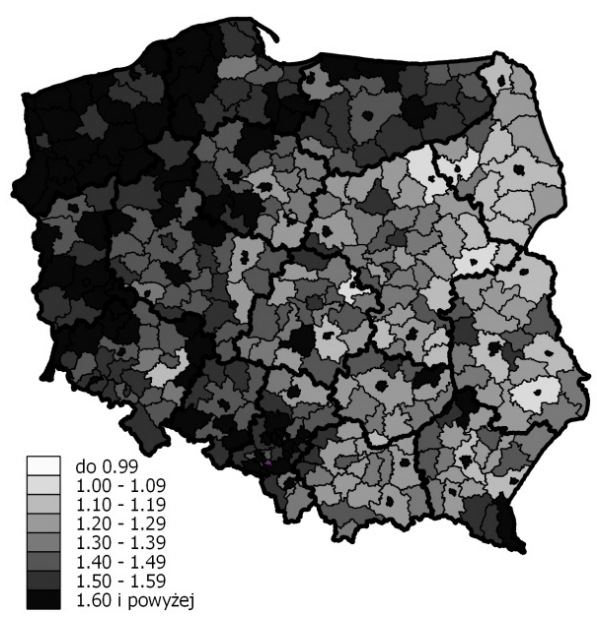

Rysunek 17. Dynamika udziałów ludności w wieku $65+$ w powiatach w latach 2002-2020 (2002 = 1,0)

Źródło: GUS; opracowanie własne

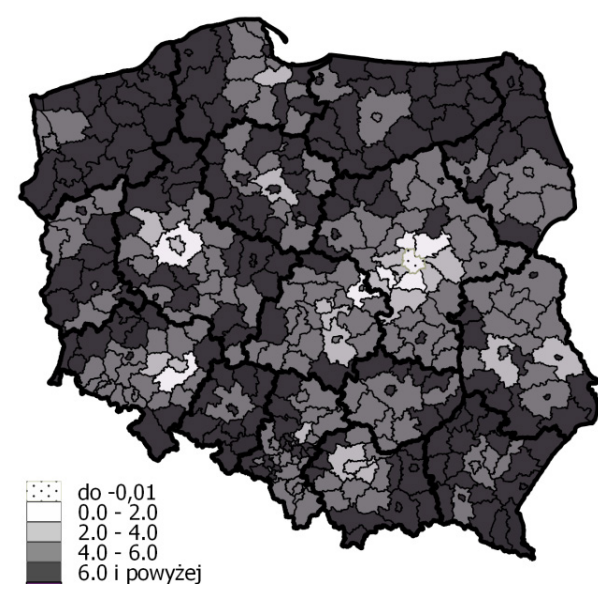

Rysunek 18. Wskaźnik starzenia się demograficznego $W_{S D}$ w powiatach w latach 2002-2014

Źródło: GUS; opracowanie własne

\section{Podsumowanie}

Od okresu transformacji ustrojowej struktura wieku populacji Polski uległa znacznym przemianom przejawiającym się przede wszystkim spadkiem udziału dzieci (0-14 lat) i wzrostem odsetka ludności starszej (65+). W perspektywie kolejnych lat można spodziewać się dalszego wzrostu starszej z tych frakcji, przy spadku udziału grupy środkowej (15-64 lata) i względnie stabilnym odsetku dzieci. Sytuacja taka będzie wynikać z faktu, że próg starości demograficznej przekraczać będą kolejne roczniki wyżu demograficznego z lat pięćdziesiątych XX wieku, a osoby napływające do subpopulacji w wieku produkcyjnym (utożsamianej z potencjalnymi zasobami pracy) nie będą rekompensować liczebnie ludności ją opuszczającej i przechodzącej do frakcji w wieku poprodukcyjnym.

Zaawansowanie starości demograficznej w Polsce jest zróżnicowane terytorialnie. Obecnie najwyższe obserwowane jest w miastach województw łódzkiego i świętokrzyskiego oraz na obszarach wiejskich w województwie podlaskim. Relatywnie najmłodszą populacją legitymują się obszary wiejskie zlokalizowane w województwie pomorskim. Zróżnicowane przestrzennie jest także tempo procesu starzenia się populacji. Obecnie szybciej starzeją się miasta, szczególnie duże pod względem liczby mieszkańców, co wynika zarówno w niskiego poziomu dzietności, jak i często ujemnego salda migracji ludności. W przyszłości wyższego tempa procesu starzenia się doświadczą głównie obszary legitymujące się obecnie relatywnie niskim zaawansowaniem starości. 
Wspomniane przemiany w strukturze wieku ludności Polski generują wiele niekorzystnych następstw, spośród których najpoważniejszy jest spadek wydolności systemu emerytalnego, opartego w znacznym stopniu na repartycji (szczególnie w sytuacji, gdy subpopulacja „wchodząca” na rynek pracy będzie w długim okresie mniej liczna od frakcji go opuszczającej), a także zmniejszanie się potencjalnych i realnych zasobów pracy ${ }^{9}$. Sytuacja ta zmusza do podejmowania różnorodnych działań mających na celu łagodzenie tych skutków, m.in. zwiększenie aktywności zawodowej ludności ${ }^{10}$. Istotną kwestią jest także zwiększenie w długim okresie poziomu dzietności.

\section{Bibliografia}

Abramowska-Kmon A. (2011), O nowych miarach zaawansowania procesu starzenia się ludności, „Studia Demograficzne”, nr 1(159), s. 3-22.

Cieślak M. (2004), Pomiar procesu starzenia się, „Studia Demograficzne”, nr 2(146), s. 3-16.

Długosz Z. (1998), Próba określenia zmian starości demograficznej Polski w ujęciu przestrzennym, „Wiadomości Statystyczne”, nr 3, GUS, Warszawa.

Gavrilova N.S., Gavrilov L.A. (2009), Rapidly aging populations: Russia/Eastern Europe, [w:] P. Uhlenberg (ed.), International Handbook of Population Aging, vol. 1, Springer.

GUS (2014a), Prognoza dla powiatów i miast na prawie powiatu oraz podregionów na lata 2014-2050 (opracowana w 2014 r.), http://stat.gov.pl/obszary-tematyczne/ludnosc/prognoza-ludnosci/prognoza-dla-powiatow-i-miast-na-prawie-powiatu-oraz-podregionow-na-lata2014-2050-opracowana-w-2014-r-,5,5.html [dostęp: 18.02.2016].

GUS (2014b), Prognoza ludności na lata 2014-2050, Warszawa.

GUS (2014c), Sytuacja demograficzna osób starszych i konsekwencje starzenia się ludności Polski w świetle prognozy na lata 2014-2050, http://stat.gov.pl/obszary-tematyczne/ludnosc/ludnosc/ sytuacja-demograficzna-osob-starszych-i-konsekwencje-starzenia-sie-ludnosci-polski-w-swietle-prognozy-na-lata-2014-2050,18,1.html [dostęp: 22.07.2015].

GUS (2015a), Bank Danych Lokalnych, http://stat.gov.pl [dostęp: 11.01.2016].

GUS (2015b), Rocznik Demograficzny 2015, Warszawa.

Holzer J.Z. (2003), Demografia, PWE, Warszawa.

Kaa D.J. van de (2002), The idea of a Second Demographic Transition in Industrialized Countries, Paper presented at the Sixth Welfare Policy Seminar of the National Institute of Population and Social Security, Tokyo, Japan, 29.01.2002, http://www.ipss.go.jp/webj-ad/WebJournal. files/population/2003_4/Kaa.pdf [dostęp: 10.02.2010].

\footnotetext{
${ }^{9}$ Ludność w wieku produkcyjnym stanowi potencjalne zasoby pracy, aktywna zawodowo zaś (bez względu na wiek) realne zasoby pracy. Należy zaznaczyć, że ich rozmiary w dużym stopniu określone są wiekiem ,wejścia” na rynek pracy (który w Polsce opóźnia się z uwagi na wydłużenie okresu edukacji) oraz granicą wieku emerytalnego. Zasoby pracy (potencjalne i realne) determinowane są także przez wiele innych czynników, m.in. demograficznych, ekonomicznych, prawnych i społeczno-kulturowych (zob. Kryńska, Kwiatkowski, 2013: 87-90).

${ }^{10}$ Jednym z takich działań było wprowadzenie w 2012 roku ustawy wydłużającej wiek emerytalny do 67. roku życia, zarówno w przypadku kobiet, jak i mężczyzn (zob. ustawa z dnia 11 maja 2012 r.), zmienionej w 2016 roku i przywracającej poprzednio obowiązujący wiek emerytalny, tj. 60 i 65 lat odpowiednio dla kobiet i mężczyzn (zob. ustawa z dnia 16 listopada 2016 r.).
} 
Kalache A., Barreto S.M., Keller I . (2005), Global ageing: the demographic revolution in all cultures and societies, [w:] M.L. Johnson (ed.), The Cambridge handbook of age and ageing, Cambridge University Press, Cambridge.

Kirk D. (1996), Demographic transition theory, „Population Studies”, vol. 3, no. 50, s. 361-387.

Kotowska I .E. (1999), Drugie przejście demograficzne i jego uwarunkowania, [w:] I. Kotowska (red.), Przemiany demograficzne w Polsce w latach 90. $w$ świetle koncepcji drugiego przejścia demograficznego, „Monografie i Opracowania”, nr 461, Oficyna Wydawnicza Szkoły Głównej Handlowej, Warszawa.

Kowaleski J.T., Majdzińska A. (2012), Miary i skale zaawansowania starości demograficznej, [w:] A. Rossa (red.), Wprowadzenie do gerontometrii, Wydawnictwo Uniwersytetu Łódzkiego, Łódź.

Kryńska E., Kwiatkowski E. (2013), Podstawy wiedzy o rynku pracy, Wydawnictwo Uniwersytetu Łódzkiego, Łódź.

Kurek S. (1998), Zróżnicowanie przestrzenne procesu starzenia się ludności Europy w latach 1960-1996 w świetle wybranych mierników, „Czasopismo Geograficzne”, nr 69, z. 3-4, s. 261-274.

Kurkiewicz J. (red.) (2010), Procesy demograficzne i metody ich analizy, Wydawnictwo Uniwersytetu Ekonomicznego w Krakowie, Kraków.

Kurkiewicz J. (red.) (2012), Demograficzne uwarunkowania i wybrane społeczno-ekonomiczne konsekwencje starzenia się ludności w krajach europejskich, Wydawnictwo Uniwersytetu Ekonomicznego w Krakowie, Kraków.

Lesthaeghe R. (2010), The unfolding story of the second demographic transition, Research report 10-969, January 2010, Population Studies Center, University of Michigan, Institute for Social Research, http://www.psc.isr.umich.edu/pubs/pdf/rr10-696.pdf [dostęp: 17.04.2017].

Nyce S.A., Schieber S. (2011), Ekonomiczne konsekwencje starzenia się społeczeństw, Wydawnictwo Naukowe PWN, Warszawa.

Okólski M. (1990), Modernizacja społeczeństwa a przejście demograficzne, [w:] M. Okólski (red.), Teoria przejścia demograficznego, PWE, Warszawa.

Okólski M., Fihel A. (2012), Demografia. Wspótczesne zjawiska i teorie, Wydawnictwo Naukowe Scholar, Warszawa.

Rowland D.T. (2009), Global population aging: history and prospects, [w:] P. Uhlenberg (ed.), International handbook of population aging, Springer.

Uhlenberg P. (2005), Demography of aging, [w:] D.L. Poston, M. Micklin (eds.), Handbook of population, Kluwer Academic/Plenum Publisher, New York.

Ustawa z dnia 11 maja 2012 r. o zmianie ustawy o emeryturach i rentach z Funduszu Ubezpieczeń Społecznych oraz niektórych innych ustaw (Dz.U. z 2012 r., poz. 637).

Ustawa z dnia 16 listopada 2016 r. o zmianie ustawy o emeryturach i rentach z Funduszu Ubezpieczeń Społecznych oraz niektórych innych ustaw (Dz.U. z 2017 r., poz. 38). 


\section{Spatial Differentiation of the Population Ageing Process in Poland}

Abstract: The main aim of the article was to analyse the changes in the Polish population structure observed since the political transformation and expected in the next few years. The analysis focused also on the spatial differentiation of both processes, population ageing (indicated with several measures) and dynamics of population ageing in Poland in the years 2002, 2014, 2020, which were conducted at the level of voivodships, poviats and gminas. The statistical data concerning the age structure in Poland were provided by the Central Statistical Office in Poland.

Keywords: population ageing process, Poland, voivodships

JEL: J1

\begin{tabular}{|l|l|}
\hline \multirow{2}{*}{ OPEN ACCESS } & $\begin{array}{l}\text { C by the author, licensee Łódź University - Łódź University Press, Łódź, Poland. } \\
\text { This article is an open access article distributed under the terms and conditions } \\
\text { of the Creative Commons Attribution license CC-BY } \\
\text { (http://creativecommons.org/licenses/by/3.0/) }\end{array}$ \\
\cline { 2 - 2 } \\
Received: 2016-09-10; verified: 2017-04-27. Accepted: 2017-10-16
\end{tabular}

